\title{
Identifiable Corrupt Practices Among Staff and Students of Secondary Schools in Delta State of Nigeria
}

\author{
Daniel Duwovwiji Whawo \\ Michael and Cecilia Foundation College of Education, Agbarha-Otor, Delta State, Nigeria
}

\section{Email address:}

danduwo2006@yahoo.com

\section{To cite this article:}

Daniel Duwovwiji Whawo. Identifiable Corrupt Practices Among Staff and Students of Secondary Schools in Delta State of Nigeria. International Journal of Secondary Education. Vol. 3, No. 5, 2015, pp. 50-54. doi: 10.11648/j.ijsedu.20150305.12

\begin{abstract}
This survey research was conducted to ascertain if there are any identifiable corrupt practices in secondary schools in Delta State of Nigeria. It also sought to catalogue the evils which corruption has done to Secondary Education in the country. Staff and students of secondary schools were randomly selected as respondents to a validated research open-ended questionnaire designed for the investigation. Results of data analyses revealed that there are several corrupt practices in secondary schools, the most frightening one being examination malpractice. They also agreed that several evils have been introduced into the school system by corruption. A lowering of academic standard occasioned by the reluctance of students to read has resulted in poor examination performance among students. These and other social evils being practised in the system by both staff and students are depreciating the quality of education at the secondary level. It is suggested that teachers be given proper orientation to dissuade them from perpetuating evils in the school system. Teachers and parents are to combine to build up good character in children.
\end{abstract}

Keywords: Corrupt Practices, Examination Malpractice, Extortion of Students

\section{Background to the Problem}

Whereas corruption was thought to be an evil peculiar among politicians by many Nigerians, studies in transparency and accountability in the publications of UNESCO suggest that corrupt practices also go on in educational institutions. This has been ascertained by the reporter among pupils and staff of primary schools in Delta State of Nigeria.

Corruption has adversely stigmatized Nigerians in most parts of the world as she was ranked the second most corrupt nation among identified 92 countries in 2001 - 2003. This is an enough justification for the budgetary allocation to sustain the Economic and Financial Crime Commission(EFCC) and the Independent Corrupt Practice Commission(ICPC), the two dreaded anti-corruption agencies in Nigeria. The average Nigerian believes that the wealth of the nation is concentrated much on the rich minority with the poor majority dependent on them. It is corruption that has created the great gap between the rich and the poor in Nigeria and other third world countries.

Corruption among adults is a vice that is being passed on to young people. They are sometimes recruited and equipped with dangerous weapons for political campaigns and as body guards even after elections are over. It is therefore heart-aching to observe that teachers who are regarded as the custodians of good morals and leaders in academic pursuit are now engrossed in corruption.

The research effort was geared toward exploring the corrupt practices found among students and staff of secondary schools in Delta State of Nigeria. It is step in unveiling corruption in Nigeria with a zeal to propose ways to fight it to a standstill.

\subsection{The Problem}

A major problem facing Nigeria is how to exterminate corruption in the Country to improve the global perception on her. The process involves the identification of corrupt practices that people indulge in. In this exercise, the secondary school system is the focus.

The problem of this study is to find out if there are concrete corrupt practices that go on in secondary schools in Delta State. In other words, are there identifiable corrupt practices among students and staff in these institutions of learning? And if there are, do the evils have any effects on secondary education in the country? This was the problem of 
this study.

\subsection{Research Questions}

The under listed three research questions were drawn up to guide the study.

$\mathrm{Q}_{1}$ : Which are the corrupt practices in secondary schools in Nigeria?

$\mathrm{Q}_{2}$ : Which is the worst corrupt practice in secondary schools in Nigeria?

$\mathrm{Q}_{3}$ : What are the evils of corrupt practices on secondary education in Nigeria?

\subsection{Related Literature}

The international clamour on Education for All (EFA) is borne from the conviction that Education is a fundamental human right. But since it's funding, according to Transparency International (2013), is often obtained from 20 - 30 per cent of the budget of most countries, it is therefore prone to corruption from the Ministries of Education. In effect, "overcrowded classrooms and crumbling schools" where "books and supplies are sometimes sold instead of being given freely", are often observed; unauthorised fees which often force children of the poor out of school, the appointment of teachers through family connection and the sale of grades are also offshoots of corruption in schools.

In discussing the concept of corruption, Nwanze $(2012,2)$ was quick to identify some offshoots of corruption. They include bribery, nepotism, misappropriation, fraud and embezzlement; others are extortion and favouritism. He then proceeded to identify some of the causes of corruption to include weak institutional enforcement framework; lack of ethical standards in Government business; poor reward system; and extended family.

While it is true that poor and mismanaged economy could cause corruption, it may not be true that people are corrupt because of poverty, otherwise only the poor people would have been corrupt. It is on record that people who corruptly looted the treasury in developing countries are the rich. It takes the will of any one to decide either to be or not to be corrupt. There are still both rich and poor citizens who are of high moral integrity in Nigeria.

In the view of Patrinos (2013), teacher absenteeism is a major source of corruption in schools, especially where they are illegitimate. Closely related is their habit of lateness to school or leaving school before closing period. Certainly these deprive students of the full opportunity to learn during official school hours. In his research in 21 countries, Patrinos found that the rate of absenteeism in primary schools range from 11 30 per cent; the rate in Uganda is as high as 30 per cent. It is even slightly higher in Kenya. He also discovered that absenteeism rate is higher in underdeveloped countries. Hyll-Larsen (2013) equally lamented the misappropriation of US \$48million from 2004-2009 in Kenya. The leakage from the Education budget is certainly detrimental to the implementation of EFA.

The work of Chow and Nga $\{2013\}$ dwelt on bribery for admission in schools in Vietnam. The existing practice was to "prioritise admissions on the basis of geographic eligibility to applicants, meaning that priority must be given to students who are officially registered as living in the area". However, over 31 per cent of the students in the desired schools were actually ineligible but got admitted from bribes offered by their parents as the schools were of high quality. It was so wide spread that 67 per cent considered the illegal practice as "normal".

Another segment of corruption in Education explored by Leach (2013) is sexual violence in schools. While majority of teachers were proud of their profession, a small proportion of them were involved in sexual misconduct like "heterosexual behaviours, with male perpetrators targeting female victims" and homosexuality in single-sex schools. And in tertiary institutions, female staff are often harassed by male colleagues, and sometime, by daring male students. For instance, of about 560 students in Botswana, Leach found that " $20 \%$ of girls reported having been asked for sex by teachers and half accepted out of fear".

The crave for paper qualifications, the world over, especially in developing countries, has given rise to another form of corruption in schools. Transparency International has identified what she tagged "Degree Mills". In her submission, "Customers of degree mills do little or no work to earn their qualification, which is simply purchased". This has led to an increasing rate of fake certificates, diplomas and degrees through counterfeiting processes. At the degree mills centres, students of all kinds, irrespective of qualifications are admitted. For this, Transparency International has observed "Wikipedia page dedicated to house pets that have all successfully 'earned' degrees from bogus universities".

In discussing academic integrity and misconduct, Bretag (2013) opined that academic integrity encompasses the five values of honesty, trust, respect, fairness and responsibility. This demands that teaching, research and learning are conducted honestly and fairly by staff and students. The negation of academic integrity include "plagiarism, cheating, unauthorised collaboration, the theft of others' work, paying for assignments from the internet, the falsification of data, the misrepresentation of records, fraudulent publishing and other actions that undermine the integrity of scholarship and research". It is sad to note that these vices now abound in most tertiary institutions all over the world.

The appointments of headship in Schools, Colleges and Universities are now being based on political affiliation instead of quality performance at a competitive selection interviews. In some African countries, according to Salmi and Helma (2013), Heads of States appoint senior members of staff in tertiary institutions. This corrupt method of appointment has favoured the introduction of unwholesome vices by way of reciprocation into the tertiary institutions. This has equally eroded the clamour for autonomy as fiscal accountability is now mortgaged by conscience in a bid to be loyal to the politicians through whose efforts one gained the employment.

In a Cambodian (1991) programme of integrating 
anti-corruption in School Curricular, secondary school students were given an opportunity to discuss "the source of their family income". It was meant to ascertain if it came from fraud of public or State assets, from exploitation of other people or from the abuse of power for private gain. They also examined why corruption breed social injustice. This is an indication that corruption in school has become a global issue.

Among others, Nwanze also identified evils of corruption to include wastage of skills and time, political instability, reduction in quantity of goods and services and upset of ethnic balance. It could cause the erosion of confidence in democratic structures, undermine effective governance, proliferation of abandoned projects, examination malpractice, distortion of financial surveillance and regulations. Sometimes, it leads to miscarriage of justice.

\section{Methodology}

This study is a survey among staff and students to ascertain if there are any corrupt practices in the secondary schools.

Specifically, 6 (3 urban and 3 rural) secondary schools were randomly selected from each of the three Senatorial Districts in Delta State. From these 18 schools, 300 students made up of equal number of both males and females and 350 tutors (150 males and 200 females) were randomly chosen. Ten (10) Research Assistants helped in the administration of the open-ended questionnaires. A total of 291 or $83.18 \%$ of the tutors and 178 or $59.33 \%$ of the students returned completed questionnaires. Many of the students who returned their questionnaires could not express themselves intelligibly.

\subsection{Presentation of Data}

Table 1a. Corrupt practices among secondary students identified by their teachers.

\begin{tabular}{llll}
\hline S/No. & Corrupt Practices & c.f & \% \\
\hline 1. & Examination malpractice & 147 & 31.41 \\
2. & Cultism & 90 & 19.23 \\
3. & Raping of female students/sexual & 42 & 8.97 \\
4. & immorality & 38 & 8.12 \\
5. & Stealing; fraud & & 6.41 \\
6. & Extortion of money/materials from female & 30 & 6.41 \\
7. & students & 30 & 5.13 \\
8. & Bribing of teachers to pass examinations & 24 & 3.21 \\
9. & Cheating & 15 & 2.56 \\
10. & Rudeness/ stubbornness to teachers & 12 & 1.92 \\
11. & Drug abuse/smoking of weeds & 9 & 1.92 \\
12 & Bulling lies & 9 & 1.28 \\
13. & Pornography Truancy & 9 & 1.28 \\
14. & Fighting & 6 & 0.64 \\
15. & Impersonation & 6 & 0.64 \\
16. & Indecent dressing & 3 & 0.42 \\
17. & Lateness to school & 3 & 0.42 \\
& TOTAL & 2 & 100.00 \\
\hline
\end{tabular}

The information obtained from the retrieved questionnaires are presented to answer the research questions. The responses in each Table are shown in cumulative frequencies (c.f) with corresponding percentages and arranged in decreasing order.
$\mathrm{Q}_{1}$ : Which are the corrupt practices in Secondary Schools in Nigeria?

To answer this question, both staff and students in the secondary schools were, in their opinions, asked to list the corrupt practices they have observed among students and staff in secondary schools. The responses on students are shown in Tables $1 \mathrm{a}$ and $1 \mathrm{~b}$ while responses on tutorial and administrative staff are shown in Tables $2 \mathrm{a}, 2 \mathrm{~b}$ and $2 \mathrm{c}$.

Table 1 b. Corrupt practices among secondary students identified by students themselves.

\begin{tabular}{llll}
\hline S/No. & Corrupt Practices & c.f & \% \\
\hline 1. & Cultism & 84 & 25.85 \\
2. & Examination malpractice & 72 & 22.15 \\
3. & Disobedience to teachers & 42 & 12.92 \\
4. & Crazy for sex/sexual & 30 & 9.23 \\
5. & harassment/prostitution & & \\
6. & Stealing of school's/students' properties & 28 & 8.62 \\
7. & Fighting their teachers & 18 & 5.54 \\
8. & Bribery & 15 & 4.62 \\
9. & Influence from bad groups & 14 & 4.31 \\
10. & Truancy & 12 & 3.92 \\
11. & Grug abuse & 4 & 1.23 \\
12. & Virls make up to school & 3 & 0.92 \\
& TOTAL & 3 & 0.92 \\
\hline
\end{tabular}

Tables $1 \mathrm{a}$ and $1 \mathrm{~b}$ indicate corrupt practices found among secondary school students. In Table 1a, their teachers identified examination malpractice, cultism, raping of female students, stealing and extortion of female students by their male colleagues as the most prominent corrupt practices among them.

The students themselves identified cultism, examination malpractice, disobedience to teachers, sexual harassment of female students, stealing and fighting teachers as strong corrupt practices among them. The information from the teachers in Table $1 \mathrm{~b}$ and from the students in Table $1 \mathrm{~b}$ agree much; this gives credibility to the opinions independently expressed by them.

Table 2a. Corrupt practices among tutors in secondary schools identified by staff themselves.

\begin{tabular}{|c|c|c|c|}
\hline S/No. & Corrupt Practices & c.f & $\%$ \\
\hline 1. & Extortion of illegal money from students & 57 & 20.80 \\
\hline 2. & Bribery/gratification & 45 & 16.42 \\
\hline 3. & $\begin{array}{l}\text { Aiding and abetting examination } \\
\text { malpractice }\end{array}$ & 39 & 14.27 \\
\hline 4. & Sexual harassment of female students & 33 & 12.04 \\
\hline 5. & Poor attitude to work/do not want to teach & 28 & 10.22 \\
\hline 6. & Giving unmerited scores to students & 21 & 7.66 \\
\hline 7. & $\begin{array}{l}\text { Forcing students to buy } \\
\text { irrelevant/unrecommended textbooks }\end{array}$ & 15 & 5.47 \\
\hline 8. & Lateness to school & 12 & 4.37 \\
\hline 9. & Truancy/leaving school before closing & 8 & 2.92 \\
\hline 10. & Some do not complete scheme of work & 6 & 2.19 \\
\hline 11. & Talking rudely to Principals & 4 & 1.46 \\
\hline 12. & Imparting wrong knowledge to pupils & 2 & 0.73 \\
\hline 13. & Trading during school hours & 2 & 0.73 \\
\hline 14. & Telling lies & 1 & 0.36 \\
\hline 15. & Cultism & 1 & 0.36 \\
\hline & TOTAL & 274 & 100.00 \\
\hline
\end{tabular}


Table 2b. Corrupt practices among administrative staff of secondary schools identified by staff.

\begin{tabular}{|c|c|c|c|}
\hline S/No. & Corrupt Practices & c.f & $\%$ \\
\hline 1. & $\begin{array}{l}\text { Bribery to process documents/and at } \\
\text { enrolment }\end{array}$ & 48 & 16.27 \\
\hline 2. & Extortion of money from students & 42 & 14.24 \\
\hline 3. & Embezzlement/stealing/fraud & 38 & 12.88 \\
\hline 4. & Lateness to school & 30 & 10.17 \\
\hline 5. & Poor attitude to work & 30 & 10.17 \\
\hline 6. & Aiding/abetting examination malpractice & 24 & 8.14 \\
\hline 7. & Sexual harassment & 18 & 6.10 \\
\hline 8. & Poor financial accountability & 12 & 4.06 \\
\hline 9. & Frequent absence from school & 12 & 4.06 \\
\hline 10. & Falsification of data to Government & 12 & 4.06 \\
\hline 11. & Favouritism & 8 & 2.71 \\
\hline 12. & Admitting unqualified students & 7 & 2.37 \\
\hline 13. & Lobbying for promotion & 3 & 1.11 \\
\hline 14. & Shielding staff who play truancy & 3 & 1.11 \\
\hline 15. & Forging of certificates & 2 & 0.68 \\
\hline 16. & Impersonation & 2 & 0.68 \\
\hline 17. & Cultism & 2 & 0.68 \\
\hline 18. & Disrespect for rules and regulation & 1 & 0.34 \\
\hline \multirow[t]{2}{*}{19.} & Trading during office hours & 1 & 0.34 \\
\hline & TOTAL & 295 & 100.00 \\
\hline
\end{tabular}

Table 2c. Corrupt practices among tutors of secondary schools identified by students.

\begin{tabular}{|c|c|c|c|}
\hline S/No. & Corrupt Practices & c.f & $\%$ \\
\hline 1. & Take bribe from students & 42 & 19.01 \\
\hline 2. & Lateness to school & 38 & 17.27 \\
\hline 3. & $\begin{array}{l}\text { Aiding and abetting examination } \\
\text { malpractice }\end{array}$ & 28 & 12.73 \\
\hline 4. & $\begin{array}{l}\text { Teachers have sexual intercourse with } \\
\text { students }\end{array}$ & 24 & 10.91 \\
\hline 5. & Stealing of school property & 18 & 8.18 \\
\hline 6. & Collection of illegal money from students & 18 & 8.18 \\
\hline 7. & $\begin{array}{l}\text { Irregular to school/frequent absence from } \\
\text { school }\end{array}$ & 15 & 6.82 \\
\hline 8. & No longer want to teach & 12 & 5.45 \\
\hline 9. & Greed & 8 & 3.64 \\
\hline 10. & Cultism & 8 & 3.64 \\
\hline 11. & Open quarrels with colleagues & 6 & 2.73 \\
\hline \multirow[t]{2}{*}{12.} & Misuse/embezzlement of school money & 3 & 1.37 \\
\hline & TOTAL & 220 & 100.00 \\
\hline
\end{tabular}

Tables $2 \mathrm{a}, 2 \mathrm{~b}$ and $2 \mathrm{c}$ contain corrupt practices among staff of secondary schools.

In Table 2a, the staff (teaching and non-teaching) opine that teaching staff extort money from the students. They accept bribe and promote examination malpractice. In Table $2 b$, the staff revealed that administrative staff in particular, embezzle school money. They also aid and abet examination malpractice. In addition, they falsify information to Government, admit unqualified students and are involved in certificate forgery. It is indicated in the three tables that staff in secondary schools are involved in cultism.

In Table2c, the students also identified some vices among their tutors, similar to those indicated by the staff themselves. Bribery, aiding and abetting examination malpractice and sexual harassment of female students occupy nearly the same order in both Tables.

$\mathrm{Q}_{2}$ : Which is the worst corrupt practice in secondary schools in Nigeria?

The data for answering the second questions are shown in Table 3. The responses of both staff and students are separated in the Table for the sake of emphasis.

Table 3. Worst corrupt practice in secondary schools as identified by staff and students.

\begin{tabular}{llll}
\hline S/No. & Worst Corrupt Practice & c.f & \% \\
\hline & By Staff & & \\
1. & Promotion of examination malpractice & 135 & 67.16 \\
2. & Bribery to get what you want & 28 & 13.93 \\
3. & Cultism & 15 & 7.46 \\
4. & Sexual immorality & 9 & 4.48 \\
5. & Lateness to work & 7 & 3.48 \\
6. & Awarding unmerited pass grades & 3 & 1.49 \\
7. & Nonchalant attitude to work & 3 & 1.49 \\
8. & Cheating & 1 & 0.050 \\
& Total & 201 & 100.00 \\
& By Students & & \\
1. & Examination malpractice & 57 & 51.35 \\
2. & Cultism & 36 & 32.43 \\
3. & Sexual immorality/prostitution & 10 & 9.01 \\
4. & Imposition of unnecessary levies on students & 8 & 7.21 \\
& Total & 111 & 100.00 \\
\hline
\end{tabular}

The information in Table 3 indicate that the worst corrupt problem in secondary schools in Nigeria is examination malpractice. Bribery, cultism and sexual immorality are also considered high by both staff and students.

$\mathrm{Q}_{3}$ : What are the evils of corrupt practices on secondary education in Nigeria?

The responses of staff and students used for answering this question are shown in Tables $4 \mathrm{a}$ and $4 \mathrm{~b}$.

Table 4a. Evils of corrupt practices on secondary education identified by staff.

\begin{tabular}{|c|c|c|c|}
\hline S/No. & $\begin{array}{l}\text { Evils of Corrupt Practices on Secondary } \\
\text { Education }\end{array}$ & c.f & $\%$ \\
\hline 1. & Lowering of education standard & 114 & 27.21 \\
\hline 2. & Students are no longer serious with their works & 63 & 15.04 \\
\hline 3. & $\begin{array}{l}\text { Graduating half-baked students into the labour } \\
\text { market }\end{array}$ & 60 & 14.32 \\
\hline 4. & Increase in cultism /militancy/killing of people & 42 & 10.02 \\
\hline 5. & $\begin{array}{l}\text { Poor performance in external examinations like } \\
\text { WAEC and NECO }\end{array}$ & 36 & 8.59 \\
\hline 6. & Increase in cases of examination malpractice & 21 & 5.01 \\
\hline 7. & $\begin{array}{l}\text { Disobedience/disrespect for constituted } \\
\text { authority }\end{array}$ & 18 & 4.30 \\
\hline 8. & Increase in dropout rate & 15 & 3.58 \\
\hline 9. & Employment of incompetent staff & 9 & 2.15 \\
\hline 10. & Bribery & 9 & 2.15 \\
\hline 11. & Poor school management & 6 & 1.43 \\
\hline 12. & Truancy among staff and students & 6 & 1.43 \\
\hline 13. & Decrease in moral values & 5 & 1.19 \\
\hline 14. & $\begin{array}{l}\text { Secondary school certificates cannot be } \\
\text { defended }\end{array}$ & 5 & 1.19 \\
\hline 15. & No more self- reliance & 3 & 0.72 \\
\hline 16 & Laziness among staff & 3 & 0.72 \\
\hline 17. & Demotion of teachers to lower ranks & 2 & 0.48 \\
\hline 18. & Production of bad future leaders & 2 & 0.48 \\
\hline & TOTAL & 419 & 100.00 \\
\hline
\end{tabular}


Table 4 b. Evils of corrupt practices on secondary education identified by students.

\begin{tabular}{ll|ll}
\hline S/No. & $\begin{array}{l}\text { Evils of Corrupt Practices on Secondary } \\
\text { Education }\end{array}$ & c.f & \% \\
\hline 1. & Cultism has damaged lives/caused untimely & 57 & 41.61 \\
\hline 2. & death & 21 & 15.33 \\
3. & Destruction of school properties and buildings & 15 & 10.95 \\
4. & Disrespect to teachers/insulting them & 9 & 6.57 \\
5. & Led to closing down of some schools & 6 & 4.38 \\
6. & Students leave school uneducated & 5 & 3.65 \\
7. & Leads to rioting/conflict in schools & 5 & 3.65 \\
8. & Oppression of innocent students & 5 & 3.65 \\
9. & Increase in truancy rate & 4 & 2.92 \\
10. & Lowering of standard of education & 3 & 2.19 \\
11. & Most teachers do not want to teach again & 3 & 2.19 \\
12. & Corruption runs down a school & 2 & 1.46 \\
\hline 13. & Increasing rate of expulsion of students from & 2 & 1.46 \\
\hline & school & 137 & 100.00 \\
\hline
\end{tabular}

The data in Tables $4 \mathrm{a}$ and $4 \mathrm{~b}$ show that corrupt practices have done a devastating blow on secondary education in Nigeria. Both the staff and students agreed that it has led to a lowering of education standard and that most graduating students are half-baked. Lack of interest in reading with its attendant poor performance in examinations and the evils of cultism, militancy, rioting and destruction of school properties are all outcomes of corruption in secondary schools.

\subsection{Findings}

In the process of answering the research questions, the data presented revealed the following findings.

1. Corrupt practices found among secondary school students include examination malpractice, cultism, sexual immorality and bribe to pass examination, stealing and cheating. Drug abuse, fighting their tutors and truancy were also associated with them.

2. Staff of secondary schools extorted money from students, aided them to cheat at examination and sexually defiled female students. They also exhibited poor attitude to work in teaching and school attendance.

3. The three most pronounced corrupt practices in secondary schools are examination malpractice, cultism and sexual immorality.

4. Corrupt practices are causing the lowering of education standard, poor attitude to work among students and staff, disrespect to staff by students and graduation of half-baked graduates.

\section{Conclusions}

The conclusions below have evolved from the findings on data analyses in the investigation.

1. There are many corrupt practices that go on secondary schools in Delta State of Nigeria.

2. Students, as well as teachers and school administrators, are all identified with specific corrupt practices in the system.

3. Examination malpractice is identified as the worst corrupt practice in secondary schools.

4. There are devastating evils that corrupt practices have brought into secondary education.

\section{Implications for Educational Planning}

Corruption in the secondary school system has certainly been introduced by staff of the schools. The staff must be given a new orientation through training; seminars and workshops to enable them imbibe the philosophy of the transformation agenda of the Federal Government of Nigeria is crucial.

Parent-Teacher-Association should be revived in secondary schools and made functional. Training for good character formation in adolescents should be a joint responsibility of parents and teachers.

Bad behaviour is infectious on their students. Teachers proven to be engaged in corrupt practices should be sanctioned appropriately by their employers.

Staff quarters should be built in schools to reduce lateness to school. It will also enhance the services of teachers to their students after closing hours, especially in extra-curricular activities.

\section{References}

[1] Bretag, Tracy (2013), "Short Cut Students: From Academic Misconduct to Academic Integrity", Global Corruption Report: Education. London: Earthscan Pub. and Routledge.

[2] Chow, Stephanie and Nga, Dao Thi (2013), ibid, pp. 64-66.

[3] Hyll-Larsen, Peter (2013), "Corruption in Primary School Admissions", ibid, p.48.

[4] Leach, Fiona (2013), "Corruption as Abuse of Power: Sexual Violence inEducational Institutions", ibid pp.94-95.

[5] Nwanze, Chuks (2012). Corruption in Nigeria Exposed with Cases,Scams, Laws and Preventive Measures. Lagos: Control and Surveillance Associations Pub.

[6] Patrinos, Harry Anthony (2013), "Teacher Absenteeism and Loss in Schools", "Global Corruption Report: Education, op. cit., pp. 73-76.

[7] Salmi, Jamil and Helms, Robin Matross (2013), "Governance Instruments to Combat Corruption in Higher Education", ibid, p. 116.

[8] Transparency Task Force (1991), "Integrating Anti-C0rruption into School Curricula (Cambodia)", www.online.com.kh/users/csd.

[9] Transparency International (2013), Global Corruption Report: Education, op. cit.

[10] Transparency International (2013), "Transparency and Integrity in Higher Education”, ibid, pp. 134-135. 